\title{
1. Introduction to The Interplay between the EU's Return Acquis and International Law
}

L'expression «pluralisme juridique mondial» désigne ... une forme toute à fait particulière de pluralisme juridique, immédiatement induit par les phénomènes de mondialisation du droit et ses différents déclinaisons ... il décrit la multiplication des lieux de fabrication et d'application du droit qui apparaissent en dehors ou au-delà du modèle strictement étatique. Le droit ne se construit pas seulement à l'intérieur de seules sphères nationales. Il est le résultat de l'activité propre d'organisations internationales et régionales. ${ }^{1}$

\section{SETTING THE SCENE: WHY THIS BOOK?}

Analysing and understanding the relationships and interactions between various legal orders has always been at the top of my academic research agenda. Having obtained my $\mathrm{PhD}$ with a dissertation on the incorporation of international legal norms into the Hungarian legal system (in 2013), ${ }^{2}$ I was determined to undertake further research on the interactions of different legal orders - in particular, on the multi-dimensional relationship between international law and the legal order of the European Union (EU). The research leading to this book was undertaken within the framework of a four-year-long research scholarship awarded by the Hungarian Academy of Sciences (2014-18).

This book aims to explore the interactions between EU and international law in a selected field: migration law, and more specifically, the 'expulsion of aliens' (a term used by the United Nations (UN) International Law Commission (ILC)), or 'return policy' (as it is called in the EU context). Beyond my 15

1 Jean-Sylvestre Bergé, L'application du droit national, international et européen. Approche contextualisée des cas de pluralisme juridique mondiale (Dalloz 2013) 9, footnotes omitted.

2 The extended and updated version of the $\mathrm{PhD}$ dissertation was also published as a monograph titled 'A nemzetközi jogi eredetü normák beépülése a magyar jogrendsze$r b e$ ' [The incorporation of legal norms of international origin into the Hungarian legal system] (Dialóg Campus - Nordex 2013) 304 pages. 
years of practical experience and theoretical knowledge in the EU migration acquis and international migration law, my choice of topic is explained by the fact that the EU area of 'freedom, security and justice' serves as a kind of 'laboratory' 3 of innovative ideas, and can be conceived as a forerunner in the development of EU integration and the creation of new EU legal concepts. Along similar lines, these concepts can also be useful when codifying and progressively developing a given domain of international migration law (eg, expulsion of non-nationals, immigration detention).

My starting point is that the development of any scientific discipline, including legal science, is largely determined by so-called 'basic or foundational questions' and the regular and systematic questioning of them. Scholars also tend to treat the relationship between EU law and international law axiomatically, according to the well-known doctrines adopted several decades ago, in which the role of the Court of Justice of the European Union (CJEU) has been instrumental; although the re-emergence of these basic (foundational) questions and the revisiting and possible revision of previous scholarly responses have certainly added value and scientific relevance.

The relationship of the EU legal order to international law - and especially the questions relating to the place and role of international law within the EU legal order - is a complex and ever-developing one. Until the legal changes introduced by the Lisbon Treaty as of 1 December 2009, very few provisions in the EU founding treaties provided guidance on these matters. ${ }^{4}$ It has therefore mostly been left up to the CJEU to determine the relationship between international law and the EU legal order, and to develop the fundamental principles in this respect. Previously, many legal academics examined EU law from the perspective of its separateness and independence from public international law, assessing how much it does or does not have to do with international law, within which this new form of interstate (legal) cooperation originally evolved. ${ }^{5}$ The CJEU prepared the ground for such scholarly inquiry by elaborating the concept of the 'autonomy of EU law', as illustrated in its famous rulings in Van Gend en Loos (1963) ${ }^{6}$ and Costa v ENEL (1964). ${ }^{7}$ This

3 Jörg Monar, 'The Dynamics of Justice and Home Affairs: Laboratories, Driving Factors and Costs' (2001) 39 Journal of Common Market Studies 747.

4 Jan Wouters, Jed Odermatt and Thomas Ramopolopus, 'Worlds Apart? Comparing the Approaches of the European Court of Justice and the EU Legislature to International Law', Leuven Centre for Global Governance Studies Working Paper No 96 (March 2014) 4, https://ghum.kuleuven.be/ggs/publications/working_papers/2012/ 96woutersodermattramopoulos.pdf (last accessed 15 August 2020).

5 For bibliographical references, see Chapter 2, footnotes 17 and 18.

6 Case 26-62 NV Algemene Transporten Expeditie Onderneming van Gend en Loos v Netherlands Inland Revenue Administration [1963] ECR 3.

7 Case 6-64 Flaminio Costa v ENEL [1964] ECR 585. 
judge-made doctrine, established in the 1960s, was repeatedly emphasized by the CJEU and then the EU legislature while EU law was underdeveloped and needed protection and independence from external normative interferences. This concept shielded the still relatively young EU legal system both from international law (eg, see the rejection of the direct effect of multiple international agreements to which the EU has become a party, and the high bar set for the EU to be subjected to international judicial dispute settlement mechanisms), and from the legal systems of Member States (with the help of the judicial doctrines of direct effect, supremacy and pre-emption).

In international law scholarship, the European integration project has been proposed as the most obvious example of a so-called 'self-contained regime' - a theory which emerged in the legal academic discourse in the 1980s: 'Of Planets and the Universe', as Bruno Simma and Dirk Pulkowski put it in their seminal 2006 article on self-contained regimes. ${ }^{9}$ The legal nature and structural characteristics of the EU legal order (the 'planet'), both in the past and today, are tested against the concept of self-contained regimes, so as to understand how international law (the 'universe') - both positive law (eg, disconnection clauses used by Council of Europe (CoE) treaties) and legal scholarship conceives of this body of law, which has been established and developed by a regional integration organization.

After a while, alongside the well-established doctrine of the autonomy of EU law and its relative independence from the international legal order, international law was considered to form an integral part of EU law. According to the CJEU, the EU legislature is bound by relevant norms of (general customary) international law; all international agreements concluded by the EU are legally binding on the EU institutions and Member States, ${ }^{10}$ with some enjoying direct effect; and the CJEU must use (general customary) international law

8 From the early scholarship, see, for example, Max Sørensen, 'Autonomous Legal Orders: Some Considerations Relating to a Systems Analysis of International Organisations in the World Legal Order' (1983) 32 International and Comparative Law Quarterly 559-76; Bruno Simma, 'Self-Contained Regimes' (1985) XVI Netherlands Yearbook of International Law 111-36.

9 Bruno Simma and Dirk Pulkowski, 'Of Planets and the Universe: Self-contained Regimes in International Law' (2006) 17 European Journal of International Law $483-529$.

10 See, for example, Case C-286/90 Anklagemyndigheden v Peter Michael Poulsen and Diva Navigation Corp. [1992] ECR I-6019, paras 45-46; Case C-162/96, A. Racke GmbH \& Co. v Hauptzollamt Mainz [1998] ECR I-3655, paras 24, 45-46; Joined Cases C-402/05 P and C-415/05 P Kadi and Al Barakaat International Foundation v Council of the European Union and Commission of the European Communities [2008] ECR I-6351, para 291; and Case C-364/10 Hungary v Slovakia [2012] ECLI:EU:C:2012: 630 , para 44. 
at least as an interpretive tool. ${ }^{11}$ In light of the findings of the evolving case law of the CJEU, international law must be openly approached and properly accommodated within the EU's internal legal edifice. Nonetheless, the CJEU's dealings with these norms of external origin remain controversial, and in some cases even confusing (in addition to the landmark Kadi judgment, ${ }^{12}$ see Opinion $2 / 13^{13}$ and the Achmea ruling). ${ }^{14}$ The CJEU's practice in this regard is rich, diverse and highly complex, as reflected in the ensuing analysis. Given the many different manifestations of international law that come into contact with the EU legal order, the picture is so complex that a single narrative can hardly capture it. This book seeks to tell this story from the perspective of EU migration law - more precisely, the EU return acquis (termed the 'expulsion of aliens' under international law).

And it is not only the influence of international law on the EU legal order, including CJEU case law, that is scrutinized. In fact, international law in general - and certain branches in particular - have also been influenced by the effects and developments of EU law. In this regard, one may observe the increase in treaty-making activity of the EU; its participation in a growing number of international organizations (eg, see its 'enhanced observer' status in the UN); ${ }^{15}$ and its various attempts to export its norms and shape the international legal order. Dialogue and impact can be thus observed in this outward-looking direction, from the vantage point of EU law towards international law. This outward dimension - the active role of the EU in shaping and influencing public international law - is also studied in order to explore how the former influences the latter (eg, within international organizations such as the UN and the CoE; in multilateral agenda setting; and during international conferences leading to the adoption of multilateral instruments such as the Global Compact for Migration). In some cases, the EU context has served as the laboratory in which certain legal solutions, ideas and legal principles have been developed and then taken into account in different codification processes

11 On the latter, see, for example, Paul Gragl, 'The Silence of the Treaties: General International Law and the European Union' (2014) 57 German Yearbook of International Law 1-36. From the most recent CJEU case law, a very good illustration is Case C-104/16 P Council of the European Union v Front populaire pour la libération de la saguia-el-hamra et du rio de oro (Front Polisario) [2016] ECLI:EU:C:2016:973.

12 Joined Cases C-402/05 P and C-415/05 P (Kadi I).

13 Opinion 2/13 Draft agreement providing for the accession of the European Union to the European Convention for the Protection of Human Rights and Fundamental Freedoms [2014] ECLI:EU:C:2014:2454.

14 Case C-284/16 Slowakische Republik (Slovak Republic) v Achmea BV [2018] ECLI:EU:C:2018:158.

15 'Participation of the European Union in the work of the United Nations' UNGA Res 65/276 (3 May 2011) UN Doc A/RES/65/276. 
of international law. To conceptualize this outward-looking relationship, the book distinguishes, where possible, between the influence of the EU as a political actor and the influence of the EU legal order per se. Given the EU's increased role on the international plane as a self-standing actor and a global player (see the aforementioned examples), the EU as an institution or political entity is more likely to influence the development of international law than its own legal order, strictly speaking.

This in-depth examination of the EU's contribution, in both senses outlined above, to the development of public international law (both hard law and soft law), codified by the Lisbon Treaty for the first time in primary EU law (Articles 3(5) and 21 of the Treaty on European Union (TEU)), helps to paint a fuller picture of the new and multiple - sometimes softer - ways in which EU law seeks to leave a tangible mark on universal (in the UN context) and regional (eg, within the $\mathrm{CoE}$ ) norm-creation processes. Equally important is to answer the question: why has the EU been pursuing this endeavour? One plausible explanation is norm exporting: positing EU law as a model to be followed by the wider international community.

\section{SCOPE OF SCRUTINY}

After outlining the EU's separateness from and openness to international law, as well as the ways in which the EU is trying to make its mark on universal (UN) and regional (CoE) international law, the book aims to explore, illuminate and critically analyse the interactions between the two legal systems and their increasingly complicated legal relations through a particular field of (migration) law: the expulsion of non-nationals. As a caveat, however, this research does not aim to provide a comprehensive overview of all dimensions of such interactions. Likewise, EU migration law - even setting aside the asylum acquis - is a rich terrain, comprising visa policy, border control, the fight against irregular migration, return policy, immigration detention, anti-smuggling and anti-trafficking measures, as well as labour migration and other forms of legal migration, coupled with the external dimension of these policies. Return/expulsion of non-nationals is only one segment of this legal kaleidoscope. My scholarly inquiry focuses on the regulation of the "expulsion of aliens' (in UN language), or 'the return of illegally staying third-country nationals' (in EU language), under the respective legal orders. The reasons for this choice are manifold and are summarized below, together with an explanation of why 'migration policy' - and more precisely, the 'expulsion of aliens' - have been selected to support the more general claims on the interactions between international law and EU law.

First, international migration is a very diverse and complex phenomenon, with numerous causes and characteristics. It has been dubbed the 'megatrend' 
of the twenty-first century by the International Organization for Migration (IOM) $:{ }^{16}$ at the end of 2019, approximately 272 million people were involved in international migration globally. ${ }^{17}$ From among the immigration law enforcement measures taken against non-nationals (aliens), expulsion by immigration or other authorities affects several million people worldwide every year. By way of illustration, an annual 400000 to 500000 'illegally staying third-country nationals' were formally expelled from EU Member States in the past few years; ${ }^{18}$ and of those, an annual 170000 to 180000 people were returned to countries of origin and transit by Member States. ${ }^{19}$ This therefore represents a legal phenomenon that is regulated by international law, supranational (EU) law and individual national legal systems, in relation to which there is considerable and extensive state practice in place, in addition to the continuously expanding body of international and domestic case law.

Second, as far as EU law is concerned, the EU return acquis represents one of the most progressive return-related codifications worldwide. In this policy area, which is about to become an exclusive EU competence, the key legal instrument is the Return Directive (2008/115/EC). The Return Directive

16 Remarks - Mr William Lacy Swing, Director General, International Organization for Migration to The High-Level Dialogue on International Migration and Development of the 68th Session of the United Nations General Assembly, 4 October 2013, United Nations Headquarters, New York, 1, https://papersmart.unmeetings.org/media2/ 158050/21e-international-organization-for-migration.pdf (last accessed 15 August 2020).

17 United Nations Department of Economic and Social Affairs, Population Division - International Migration, International migrant stock 2019, www.un.org/en/ development/desa/population/migration/data/estimates2/estimates19.asp (last accessed 15 August 2020).

18 European Commission, Return \& readmission, http://ec.europa.eu/dgs/home -affairs/what-we-do/policies/irregular-migration-return-policy/return-readmission/ index_en.htm (last accessed 15 August 2020).

19 For instance, in 2013, the EU Member States effectively removed some 166470 illegally staying third country nationals subject to a return decision [see 'Communication from the Commission to the European Parliament and the Council, 5th Annual Report on Immigration and Asylum (2013)' COM (2014) 288 final, 4-5]; this figure was 186630 in 2012 (the nwumber of irregular migrants who were issued a return decision and then actually returned) [see 'Communication from the Commission to the European Parliament and the Council, 4th Annual Report on Immigration and Asylum (2012)' COM (2013) 422 final, 4]. The latest statistics on return rates from the EU depict worsening effectiveness of returns: the number of implemented returns in 2017 decreased by almost 20 per cent compared to the previous year: from 226150 in 2016 to 188920 in 2017. Throughout the EU, this translates into a drop from 45.8 per cent in 2016 to 36.6 per cent in 2017 (see 'Communication from the Commission to the European Parliament and the Council, Progress report on the Implementation of the European Agenda on Migration' COM (2018) 301 final, 14-15). 
sets out common standards and procedures in Member States for returning 'illegally staying third-country nationals', which are inspired to a certain extent by general and regional international law. A considerable number of CJEU judgments have already interpreted it and elucidated its provisions (see Chapter 3, Table 3.4). Other pieces of the EU acquis aimed at curbing irregular migration complement the Return Directive. These include the Directive on the mutual recognition of expulsion decisions (2001/40/EC); the Directive for transit operations in removals by air (2003/110/EC); the Joint Removal Flights Decision (2004/573/EC); the Employers' Sanctions Directive (2009/52/ EC); the Regulation establishing a European travel document for returns (Regulation (EU) No 2016/1953); and the recast Regulation on Immigration Liaison Officers (Regulation (EU) 2019/1240) (see Chapter 3, section 3). ${ }^{20}$ As regards the external side of the EU return acquis, the EU's normative action translates into an expanding network of EU-level readmission agreements. Thus far, the EU has concluded 18 such agreements with third countries and autonomous entities and some further EU-level readmission agreements are still in the making (see Chapter 5, section 7). All this represents a densely regulated area of EU migration law, increasingly pre-empted by the EU from Member State action ${ }^{21}$ in many respects.

Third, when it comes to international law, the topic of the 'expulsion of aliens' is fairly well codified under international law. The previously somewhat scattered universal rules governing the expulsion of aliens were codified by the ILC (from 2005 to 2014); the result was a set of draft articles adopted at second reading and submitted to the UN General Assembly (UNGA) in October 2014. The UNGA will examine anew the draft articles in its session in November 2020. This topic is also an illustrative microcosm of the current debate within the ILC over whether it should adopt 'draft articles', which could subsequently lend themselves to incorporation into a hard-law convention, or whether it should rather limit itself to the preparation of framework principles and the adoption of mere 'guidelines'. More recently, the first comprehensive universal (soft law) instrument covering almost all aspects of the international legal regime regulating the movement of people across borders was adopted

20 For the gist of the EU acquis on fighting irregular migration as well as return and readmission, see, for example, the overview in Laura Gyeney and Tamás Molnár, 'The Immigration and Asylum Policy of the European Union' in Petra Lea Láncos and others (eds), Union Policies (Eleven International Publishing 2016) 183-249.

${ }_{21}$ Within the meaning of Art 2(2) TFEU: "When the Treaties confer on the Union a competence shared with the Member States in a specific area, the Union and the Member States may legislate and adopt legally binding acts in that area. The Member States shall exercise their competence to the extent that the Union has not exercised its competence." 


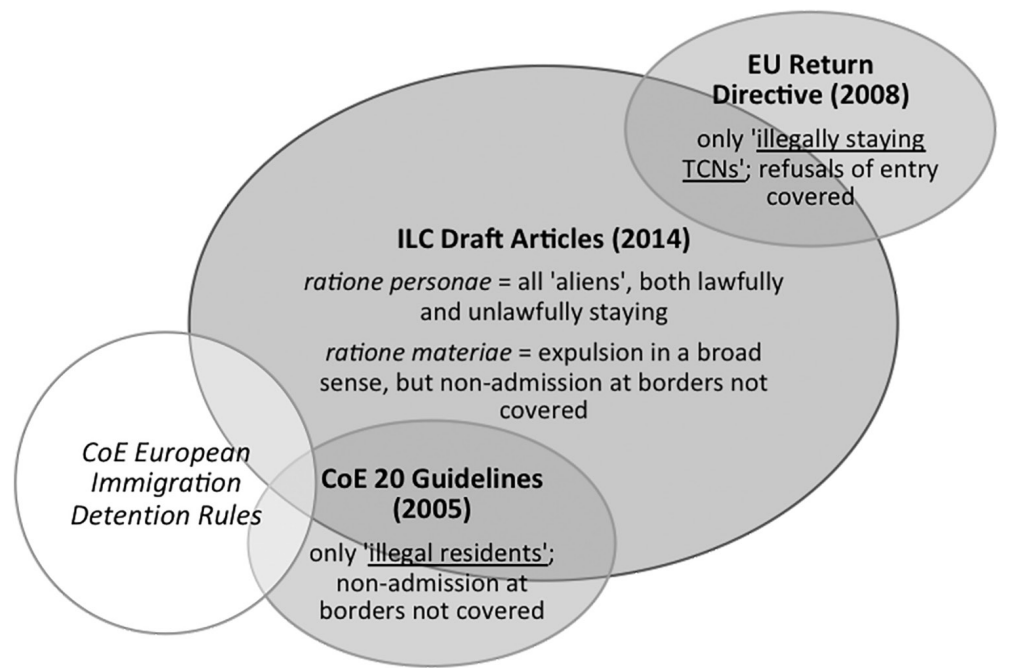

Note: Italic text $=$ codification instrument not formally adopted yet; $\mathrm{TCN}=$ third-country nationals (non-EU nationals).

Figure 1.1 Relationship of different universal and regional codification instruments regulating the expulsion of aliens

under the aegis of the UN (December 2018): the Global Compact for Safe, Orderly and Regular Migration (GCM). The GCM equally deals with issues of 'safe and dignified return, readmission and sustainable reintegration' (Objective 21); and its commitments on immigration detention (Objective 13) are also of vital importance in this regard. At the regional level, the $\mathrm{CoE}$ has conducted noteworthy standard-setting activities - see notably the 2005 Twenty Guidelines on Forced Return, as recommendations addressed to $\mathrm{CoE}$ States; and the codification of European rules on the administrative detention of migrants remains ongoing beyond 2020. These codification instruments - excluding the GCM, which is a different kind of document with an all-encompassing nature - and the EU Return Directive have slightly different scopes of application. For these variations, see Figure 1.1.

This book aims to paint a legally sound and sufficiently elaborate picture of how and through which channels one legal order influences and shapes the other in a selected area (the expulsion of non-nationals), and to understand in detail the interactions and interplay between EU law and international law in that field. The engagement of the EU's return acquis with international law is thus conceived as a two-way process. In order to shed more light on these issues, the book carefully scrutinizes the practice of the EU, the UN and other 


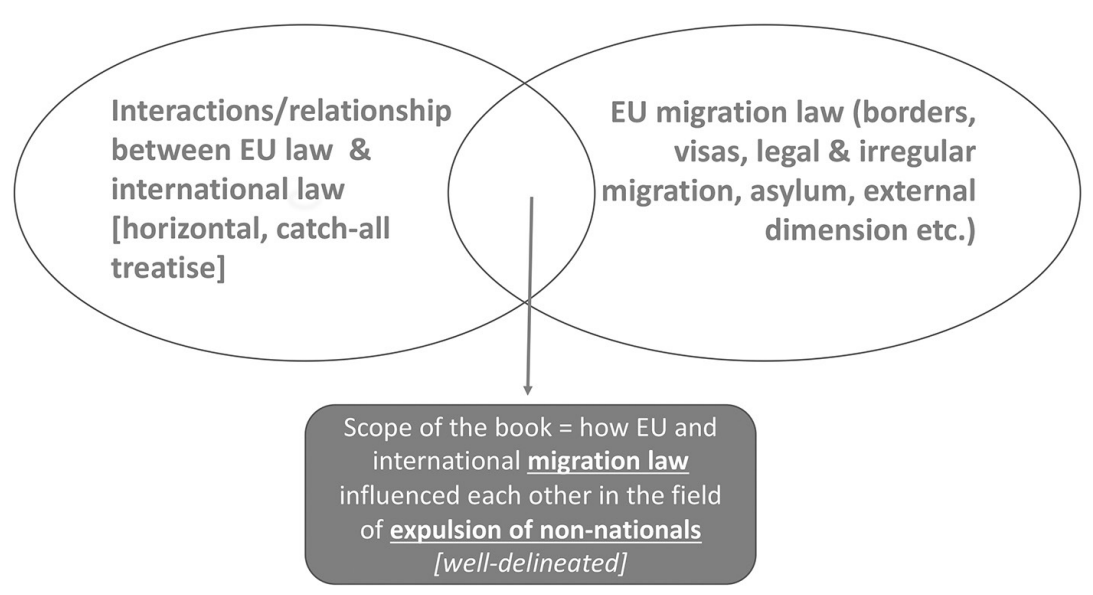

Figure $1.2 \quad$ Scope of the research

bodies in charge of codifying international migration law, as well as the jurisprudence of international courts and the CJEU in this regulatory field. There is much room to map these interactions, normative processes and dialogues in the area of the return of irregular migrants, and to explain these phenomena, including through use of the comparative method.

This book aims to complement the existing literature and to fill in some gaps. Despite their many obvious interconnections, EU and international law are often studied and practised in different spheres. ${ }^{22}$ While it is natural for each to insist on its own unique characteristics, and in particular for EU law to emphasize its 'autonomy', important insights may be lost because of this exclusionary approach - both from the institutional (constitutional) perspective and from the point of view of substantive areas of law such as migration law. In a similar vein, little legal scholarship has thoroughly studied the relationship between international (migration) law and the EU migration acquis (in the literal meaning of the term, asylum acquis excluded) - either generally or in the specific field of the expulsion of aliens - from either side of the dyad. Therefore, the issue of whether and to what extent EU legislation has been inspired and influenced by international migration law - especially as concerns EU return policy - is largely unexplored. And vice versa: the contribution of the EU and its legal order to the conceptualization and development of interna-

22 On this phenomenon, see, for example, Ramses A Wessel, 'Studying International and European Law: Confronting Perspectives and Combining Interests' in Inge Govaere and Sacha Garben (eds), The Interface between EU and International Law. Contemporary Reflections (Hart Publishing 2019) 73-97. 
tional law governing the expulsion of non-nationals - at either the universal or the regional level - has received little academic attention. This book attempts to bridge these gaps. Figure 1.2 illustrates the niche that this research explores in greater detail.

\section{OVERVIEW OF THE BOOK'S STRUCTURE}

This book is divided into five main blocks of analysis. Chapter 2 sketches out the general framework of the relationship between EU law and international law, primarily seen from the perspective of the EU legal order. It examines the autonomy of international organizations in general and the autonomy of the EU law in particular, and thoroughly analyses the external dimension of this foundational concept developed in the EU legal order (vis-à-vis international law). It also elaborates on various legal techniques and substantive requirements which are meant to preserve the autonomous character and functioning of EU law from the perspective of the external aspect of autonomy. By mapping the key ways in which international law is received in the autonomous EU legal order, the chapter also prepares the ground for understanding how a selected field of EU law (ie, the EU return acquis) positions itself towards international law.

Chapter 3 zooms in on EU migration law, and the expulsion of aliens in particular. This chapter examines how the 'autonomy' concept functions in a given field of the EU acquis. It also scrutinizes the influence of international migration law and human rights law on the EU migration acquis - particularly on the expulsion of aliens ('return policy' in EU parlance). In addition, it compares the seemingly different approaches towards norms of international origin by the EU co-legislators and the CJEU in the field of return.

Chapter 4 switches the logic and deals with the interactions of the two normative orders the other way round: it examines the ways in which the EU (and EU law) seeks to shape the international legal order. In addition to general considerations concerning the EU as a norm-setting global actor, the EU's contribution to the work of UN bodies such as the ILC and the UNGA Sixth Committee (Legal) is analysed more closely and specifically. The EU norm-exporting endeavours at the UN level are paired with such efforts within the regional frameworks. Hence, a similar analysis is conducted of how the EU and its legal standards have contributed to and shaped standard setting in the CoE (especially through soft law instruments, but also through CoE conventions via the 'disconnection clauses' and drafting suggestions).

It is then followed by the outward looking perspective (Chapter 5), which explores the impact of the EU return acquis on the international law regimes governing the expulsion of aliens - notably in relation to the work of the ILC, the processes culminating in the GCM and the CoE's standard-setting activi- 
ties. An analogous inquiry considers the impact of the expanding network of EU-level readmission agreements on the treaty-making practice of third countries on this matter, and hence at the norm-exporting power of such agreements at the international level. Chapter 6 summarizes the main findings and draws general conclusions.

This book presents the law, jurisprudence and academic literature as of 1 September 2020. 